This is the accepted manuscript version of an article that will appear in Higher Education Review, 45:2 (2017)

\title{
Universities, Expertise and the First World War
}

Julia Horne \& Tamson Pietsch

There are myriad connections between universities and war. The complex and manysided character of modern universities, where knowledge thrives under the protection of academic freedom, means that they are places of protest where war is critiqued as inhumane and brutal at the same time as sites for the production of knowledge used in conflict and for the academic education of the expert labour that fuels the defence forces of nations. Universities are also sites for the research and development of ideas and inventions that are subsequently utilised after conflicts end, through policies and practices enabling post-war reconstruction and the rehabilitation and repatriation of former service personnel. In the latter case, knowledge is not necessarily deployed solely for destructive purposes: the expertise of many disciplines-including medicine, the social sciences and the humanities - is now routinely mobilised to save lives, to rehabilitate traumatised soldiers and civilians, and to reconstitute shattered social, economic and political infrastructures. These manifold interconnections between universities and war not only tell us much about the place of universities in national and civil life, but also about the nature of knowledge production and the mobilisation of expertise. This special issue explores these matters as they arose during the First World War and examines the way they played out in attempts to reshape society in the 1920 s and 1930s.

Universities were established in Australia in the middle of the nineteenth century as secular and public institutions that initially offered a liberal education grounded in the classics, but expanded to include education of the professions (Horne and Sherington, 2012, pp. 4-32; Pietsch, 2013, pp. 24-32). In the early twentieth century they were institutions of knowledge in a number of senses. First, universities were institutions of civil society that fostered robust and informed debate, through the curriculum, through student societies and through the public role assumed by many of their staff. Second, they were institutions that trained professionals and experts. From doctors, lawyers, engineers and chemists, to "newer professions" such as teaching, social work, economics, and architecture, universities offered the specialised training that was needed both by practitioners and members of the public. Third, from the late nineteenth century on, universities were increasingly homes to research. Although research was still largely unsupported by government funding, across the country professors were actively engaged in the discovery of new knowledge, much of which was directly relevant to the needs of emerging societies. The First World War mobilised all these kinds of knowledge. Universities and their graduates looked for a role in the conflict and academics considered the nature of war and its causes. The need for specialist knowledge drew civilian experts into the forces and the industries that supported them, to serve as medics, engineers, chemists and translators among other roles; and professors and academics turned their attention to help solve new problems created by industrialised conflict. When the fighting stopped, many of these activities continued or were re-directed: doctors investigated treatments for new types of war-related injury such as shell-shock and facial disfigurement, researchers 
pursued new fields of interests opened up by war, and experts and publics debated plans and designs for the post-war world.

Scholarship on the First World War and its legacies is a well-developed field of historical inquiry. But until recently, the relationship between universities and the first global conflict of the twentieth century has been neglected. In the last few years, however, there has been an international reassessment of the relationship between universities, war and society as transformative, both during and after the conflict (Pietsch, 2012; 2013; Irish, 2015; Windsor, 2014). By pointing to the international nature of scholarly networks, to the way they mobilised and fostered academic expertise in the service of war, and to their lasting effects into the 1920s and 1930s, this emerging literature contends that universities should be central to the ways historians understand both the First World War and the period after it.

This special issue of History of Education puts university expertise and knowledge at the centre of historical analysis, with each article unfolding an aspect of this surprisingly rich topic. The contributors each ask how university education, expertise and professional experience were applied both in the context of the inhuman conditions of war, and - as significantly - in the peace that followed. Their focus is principally on Australian institutions and individuals, but they also include political and artistic movements that took place abroad but had influence locally, such as British liberalism, internationalism and modernism. The war drew Australian university graduates to Europe and North Africa in unprecedented numbers. In order to understand the impact of the First World War on these university men and women, and conversely, their impact on the Australian nation in the 1920s and 30s, we need to follow them across borders, battle-lines and the neat periodization of 1914-1918. Doing so, these articles show, opens new perspectives on old themes.

$\diamond \diamond \diamond$

Universities in nineteenth-century Australia were not training grounds for an officer class. Although the New South Wales government had approached the University of Sydney in the late 1880s to establish superior military training, due to a lukewarm reception the proposal was soon withdrawn. Voluntary student corps at Australian universities were more successful, but they relied on the willing support of professors.

In 1905, following the South African War (1899-1902), the Australian Commonwealth government approached Australian universities to consider introducing an academic and examination program in military studies. The approach was prompted by the example of the Advisory Board on Military Education in the United Kingdom, which supported programs to encourage undergraduates who wished to be appointed to a commission in the British Army upon graduation. The proposal came with no funding, and was politely declined by the Universities of Melbourne, Adelaide and Tasmania. Sydney University was intrigued, however, by the possibilities of the academic study of "the principles underlying the Military Art”[1]. In 1907, it introduced a diploma of Military History and Science; a course of study, said its newly appointed director Brevet Col. Hubert J. Foster, that was "more suited to the University spirit" because it was designed to "give a general knowledge of the principles and practice of war, such as could only be drawn from a study of past 
campaigns"[2]. From 1910, lectures were made free to all undergraduates to encourage participation by the broader student population, and this resulted in an increase in numbers. But even with the promise of an officer's commission, very few students went on to graduate with the diploma. The idea of military science as an academic pursuit did not have much purchase, and after 1914 student numbers declined to the point that in 1916 none enrolled. The Department was formally closed in 1918 (Turney et al., 1991, pp. 407-410).

With the outbreak of war in Europe, these early attempts to develop the field of military studies as an intellectual and scientific discipline in Australia were swiftly replaced by a more urgent utilitarian call to arms. Special regulations were passed to allow male students - particularly those studying medicine - to complete their courses quickly, recruiting events were organised, rifle clubs and Officers' Training Corps were convened or established and classes set aside for compulsory drill, ambulance, and signal practice. University staff, students and graduates responded swiftly and volunteered in large numbers for service in what became the Australian Imperial Forces. Others travelled to Britain to serve in the British Army. Or if they were women, as Julia Horne writes in this issue, they joined any number of British women's units. By our estimate at least 6,500 Australian university-educated men and women served in Europe and the Middle East. In doing so, they supported Australian Prime Minister Andrew Fisher's vow to "help and defend Britain to the last man and the last shilling"[3].

Yet the Australian and British armed forces were slow to realize the value of university education and professional training in what was a new kind of war - a war in which science and knowledge were to play a critically important role. Medical and engineering training was highly valued by the armed forces but outside these disciplines, which had longer associations with the military, the early stages of the war saw university personnel enrolling in the forces alongside everyone else - some by inclination, others under orders. This policy had consequences that were at once senseless and tragic. H.G.J. Moseley, a University of Sydney graduate and a brilliant physicist engaged in pioneering work under Ernest Rutherford, died at Gallipoli: he was just one of the prominent scientific minds killed early in the war (Irish, 2015, pp 41-45; Rutherford, 1915).

But by mid-1915, circumstances on the battle field were beginning to change. As the ANZAC troops landed in the Dardanelles, mustard gas was used by the Germans at Ypres (Stanley, 2005). Its devastating effects, together with the dawning realisation that the war would not be a quick one, demonstrated to the Allied High Command the potential value of universities as sites of scientific expertise. They began to be rapidly mobilized in new ways. Chemists were needed to produce explosives and dyes for uniforms; physicists to design submarine detection equipment and warplanes; geologists and engineers to conquer the difficulties of trench warfare and tunnelling; and doctors and bacteriologists for the battle against the horrors that were beginning to emerge as a consequence of new types of warfare. The First World War became a conflict fought as much by experts as by expeditionary forces, and in this new kind of war Australian university graduates played a crucial role (Pietsch, 2013; Macleod, 1989; 2000). This shift also drew in the professions, as Tamson Pietsch shows in her piece in this issue on dentistry. The services offered by Australia's dental practitioners had initially been rejected by Australian Army leaders, but this changed in 1915 after 
the introduction of the new policy towards university graduates. Six Dental Officers all university trained - were appointed by the AIF, leading to the subsequent creation of a graduate-run Dental Corps that provided expert dental care to large numbers of Australian soldiers, many for the first time in their lives. For these soldier-dentists, the battles of the First World War were bacterial and bodily. Their expertise was the weapon in a war against dental caries.

While the war transformed the nature and status of university expertise, both on the battlefield and at home, it also transformed the political philosophies and commitments of many academics and intellectuals. In this issue, Geoffrey Sherington examines the war work of two eminent British liberal historians of the early twentieth century, James Bryce and Herbert Fisher. As he shows, the war brought about an intellectual crisis for many academics who once had shared a common faith in freedom of enquiry, as well as in peace and prosperity as the foundation of academic life. John Moses's article considers how these ruptures within British liberalism affected the ideas and work of Sydney University's Challis Professor of History George Arnold Wood. A prominent and controversial critic of the South African War, Wood had grounded his opposition in a progressive Gladstonian liberalism that he believed emphasised humanity and decency and supported the quest of subject peoples for independence. These were the values that Wood understood the Allies to be defending in 1914. Both Moses' and Sherington's articles reveal how professors such as Wood, Bryce and Fisher saw their academic role as one of public duty and responsibility. For Wood and for Bryce, this meant informing the community about the historical roots of the crisis in which the British Empire had become involved with imperial Germany; for Fisher, it entailed active political service and educational reform. These two articles remind us that the effect of the war on universities extended far beyond the recruitment of experts. As sites of civil society and political thought, the war forced universities and those who worked in them, to rethink pre-war ideas and to re-assess their public implications in ways that stretched across national boundaries.

What happened after the guns fell silent? The official picture of Australia's returning servicemen and women was shaped by C.E.W. Bean's claim that they "merged quickly and quietly" back into Australian society (Bean, 1983). This "quietist tradition" has been challenged by recent studies highlighting the on-going struggles of veterans, their families and repatriation systems to cope with return (Garton, 1996; Lloyd and Rees, 1994). There has also emerged a rich historiography on war grief, mourning, memorialisation and the burden on families caring for injured and ill veterans (Damousi, 2001; Larsson, 2009; Ziino, 2007; Jalland, 2006). More generally, the return of veterans is integrated into larger general studies of the interwar years that highlight the political, social and economic difficulties then facing Australia, the longterm bitterness arising from conscription, and the general retreat into a defensive culture more concerned with protection, nationalism and Empire loyalism in contrast to the confident social experimentation of early Federation (Garton, 2014; Macintyre, 1999; Williams, 1995). The specific roles of returned soldiers in post-war Australia have received passing attention in such areas as post-war riots (Evans, 1988) and their place in the emergence of the "Australian right" (Moore, 1989; Cathcart, 1998). There is, of course, a vast and rich tradition of scholarship on the ANZAC legend and its development in post-war Australia (Seal, 2004; Holbrook, 2014; Scates, 2006). 
Noteworthy here is the pioneering work of Ken Inglis on the emergence of ANZAC as a "secular religion" in the post-war era (Inglis, 1998).

As Inglis and others have shown, memorialisation began as the losses on both sides mounted, and was as important at local levels in framing personal and public memory as it was within the nation-state (Winter, 1994; Inglis, 1998). This literature is developed in this issue by Kate Darian-Smith and James Waghorne, who examine the way universities and their colleges became early sites of memory-shaping. As they show, campus memorials were a means through which Australian universities insisted that their rendering of specialised expertise to the war effort be acknowledged, even as they debated the meaning of that service. Ann Stephen also takes up the themes of expertise and memory in her article on the paintings of J.W. Power, a Europeantrained Australian modernist painter who served as a doctor in the Royal Army Medical Corps during the war. She asks if Power's series of paintings (simply called Têtes) from the 1930s, which depict human heads in what Stephen calls a "Cubist shattering of a single fixed perspective", might not also offer insight into the artist's previous career as a war surgeon. Did his experience of war, of the shattered limbs and the half-blown away faces that he was expected to put back together, help frame his post-war decision to give up his medical career and train as an artist? Can we see these paintings as a palimpsest of medical knowledge and expertise, of war experience and subsequent artistic training as Power negotiated his way into the modern era? As these two articles demonstrate, the politics of commemoration, both public and personal, were never just about looking backwards. They were also about the kind of world to be built after the conflict.

The transformations wrought in post-war Australia by the return of experts, by their contribution to the development of Australian society and culture in the interwar years, by the rise of the professions and the impetus to Australian research, particularly in universities after 1919, have received scant historical attention. There are some noteworthy biographies where these themes are evident. Serle's book on John Monash is a classic example (Serle, 1982). Some histories of professions note the impact of the war, particularly in the fields of psychology and psychiatry (Damousi, 2005, Garton, 1988) but also pharmacy, nursing and others (Bassett, 1998; Harris, 2011). Histories of universities have generally seen WWI as a crucial turning point, noting the impact of increased government emphasis on research (Selleck, 2003; Horne and Sherington, 2012; Pietsch, 2013), and the rising number of women going to university (Mackinnon, 1986; Horne, 2015). Australian histories of intellectual culture, notably those on Australian liberalism (Rowse, 1978) and the growth of the social sciences (Macintyre, 2010; Gray et al, 2012), have done much to illuminate the intellectual currents of the interwar years (Head and Walter, 1988) but their focus has been at the level of broad intellectual movements and currents of opinion, rather than on the precise impact of experts who brought their war experience to bear on specific areas of professional life and whose status as experts was enhanced by it.

The war continued after the peace in ways that the frequently deployed trope of "frontline" and "home front" fail to capture. Although this dichotomy is useful for its recognition of the gendered nature of war, and the difficulties repatriated soldiers faced in moving from the masculinised space of the battle field to the feminised space of home, it does not help us understand the links that Tamson Pietsch and others identify in this issue, between the wartime battlefield and the reshaping of 
professional activity in the 1920s and 1930s. Julia Horne's concept of the "knowledge front" is useful in explaining how both men's and women's experience of war intersected with expertise-focussed activities like research and education into the 1920s and 1930s. By drawing on the professional lives of two university-educated women-the medical researcher Elsie Dalyell and the teacher-activist Lucy Woodcock-she explores how the concept of "knowledge front" opens out a third space for examining "war" in which women, not only men, are active participants. The concept also shows the continuity of intellectual and scientific activity from war to peace, with many university-educated men and women finding niches in a post-war world that enabled them to contribute their expertise.

While the First World War ended in Europe on 11 November 1918, its ramifications were long-lasting, so much so, that in some ways it is artificial to see the war as having temporal boundaries from 1914 to 1918 (Irish, 2015, p. 191). This was especially true for Australian troops, for whom demobilisation was a lengthy affair. In the case of some university-educated service men and women, it was even longer before they returned to Australia. The research website, Beyond 1914: The University of Sydney and the Great War has gone some way to breaking down the perception that all Australians returned immediately to Australia after the war[4]. Although most did, a significant number of university men and women took other routes. Some stayed in Great Britain to take up opportunities to develop interests and experience they had gained during war. Elsie Dalyell, who became a scientific researcher at the Lister Institute on a ground-breaking study of rickets in war-torn Vienna, was one of these. Others, like the dentist Frank Marshall, who was sponsored by the Australian government to undertaken further dental training at the University of Pennsylvania in the United States, travelled to North America, while others still went to Asia, Europe and Africa. A sustained study of these international routes of demobilisation has yet to be undertaken[5]. But of significant interest is the effect of mobility outside the usual routes of "return" to Australia, and whether it helped define a new type of peace, a renegotiation of civil society that was transformative, like a phoenix rising out of the ashes.

If the war fatally undermined the pre-war party political version of liberalism that Sherington and Moses write about, it did much to invigorate a liberal internationalism in which experts and academics played a central role. As Glenda Sluga argues in this issue, liberal internationalism inspired much of the humanitarian thinking by men and women who hoped to influence the peace-making process both directly after the war and into the 1920s and 1930s. It was an intellectual approach that largely came out of Anglo-American universities (including those in the British Empire), specifically the disciplines of the humanities and social sciences.

As Australian historians move beyond the ANZAC centenary to consider the kind of world that developed in the wake of what contemporaries knew as the "Great War", these articles show just how important the conflict was for the world of expertise. We begin this special issue with three articles that move between Australian and Europe in order to explore the idea of the "knowledge front" through the lives of two women, two dentists and an artist. These are followed by two articles on "politics and expertise", which investigate how historians, psychologists and social scientists in the UK, Europe and North America employed knowledge to understand the war and its aftermath. Finally, we return to Australia with two articles on "memory and 
understanding". From memorialisation to civil society, from liberalism and internationalism to the professions, these articles indicate that the mobilisation of university men and women exerted an influence on the production and application of knowledge and on the nature of civil society both in Australia and abroad, throughout the 1920 s and 30 s.

\section{Notes}

Report of the Senate, 1905, quoted in Turney et al., 1991, p. 408.

Brevet Col. Humbert J. Foster, quoted in Turney et al., 1991, p. 409.

Andrew Fisher, quoted in Evening News (Sydney), 1 August 1914, p. 8.

Beyond 1914: The University of Sydney and the Great War, available at: beyond1914.sydney.edu.au. Published by the University of Sydney with generous assistance from the Chancellor's Committee, St Paul's College, St Andrew's College, Women's College and St John's College.

These questions are to be explored across a new biographical project on War and Australian University men and women: Expert Nation: universities, war and 1920s \& 1930s Australia, funded by the Australian Research Council.

\section{References}

Bassett, J. (Ed.) (1998), As We Wave you Goodbye: Australian Women and War, Oxford University Press, Melbourne.

Bean, C.E.W. (1983, first published 1946), ANZAC to Amiens, Australian War Memorial, Canberra, available at: https://www.awm.gov.au/collection/RCDIG1069871/ (accessed 14 April 2016).

Cathcart, M. (1988), Defending the National Tuckshop: Australia's Secret Army Intrigue of 1931, Penguin, Fitzroy.

Damousi, J. (2001), Living with the Aftermath: Trauma, Nostalgia and Grief in PostWar Australia, Cambridge University Press, Oakleigh.

Damousi, J. (2005), Freud in the Antipodes: A Cultural History of Psychoanalysis in Australia, UNSW Press, Sydney.

Evans, R. (1988), Red Flag Riots: A Study in Intolerance, UQ Press, St Lucia.

Garton, S. (1988), Medicine and Madness: A Social History of Insanity in NSW 1880-1940, UNSW Press, Kensington.

Garton, S. (1996), The Cost of War: Australians Return, Oxford University Press, Melbourne.

Garton, S. (2014), "The Dominions, Ireland and India", in Gerwarth, R. and Manela, E. (Eds.), Empires at War 1913-23, Oxford University Press, Oxford, pp. 152-177.

Gray, G., Munro, D. and Winter, C. (Eds.) (2012), Scholars at War: Australasian Social Scientists, 1939-1945, ANU E-Press, available at: http://press.anu.edu.au?p=166981 (accessed 14 April 2016).

Harris, K. (2011), More than Bombs and Bandages: Australian Army Nurses at Work in World War I, Big Sky Publishing, Newport.

Head, B. and Walter, J. (Eds.) (1988), Intellectual Movements and Australian Society, Oxford University Press, Melbourne.

Holbrook, C. (2014), ANZAC: the Unauthorised Biography, New South Publishing, Sydney. 
Horne, J. \& Sherington, G. (2012), Sydney: The Making of a Public University, Miegunyah Press, Melbourne.

Horne, J. (2015), "The Final Barrier? Australian Women and the Nineteenth-Century Public University", in Panayotidis, E. and Stortz, P. (Eds.) Women in Higher Education, 1850-1970: International Perspectives, Routledge, New York and London, pp. 76-96.

Inglis, K. (1998), Sacred Places: War Memorials in the Australian Landscape, Miegunyah Press at Melbourne University Press, Carlton.

Irish, T. (2015), The University at War, 1914-25, Palgrave Macmillan, Basingstoke.

Jalland, P. (2006), Changing Ways of Death in Twentieth-Century Australia: War, Medicine and the Funeral Business, UNSW Press, Sydney.

Larsson, M. (2009), Shattered ANZACs: Living with the Scars of War, UNSW Press, Sydney.

Lloyd, C. and Rees, J. (1994), The Last Shilling: A History of Repatriation in Australia, Melbourne University Press, Carlton.

Macintyre, S. (1999), A Concise History of Australia, Cambridge University Press, Melbourne.

Macintyre, S. (2010), The Poor Relation, Melbourne University Publishing, Carlton.

Mackinnon, A. (1986), The New Women, Adelaide's Early Women Graduates.

Wakefield Press in Association with the University of Adelaide Foundation, Adelaide.

MacLeod, R. (1989), "The 'Arsenal' in the Strand: Australian Chemists and the British Munitions Effort 1916-1919", Annals of Science, Vol. 46 No. 1, pp. 45-67.

MacLeod, R. (2000), "Sight and Sound on the Western Front: Surveyors, Scientists, and the Battlefield Laboratory: 1915-1918", War \& Society, Vol. 18 No. 1, pp. 26-46.

Moore, A. (1989), The Secret Army and the Premier: Conservative Paramilitary Organisations in NSW 1930-32, UNSW Press, Kensington.

Pietsch, T. (2012), "'Mending a Broken World': The Universities and the Nation, 1918-36", in Beers, L. and Thomas, G. (Eds.), Brave New World: Imperial and Democratic Nation-Building in Britain between the Wars, Institute for Historical Research, London, pp. 161-180.

Pietsch, T. (2013), Empire of Scholars: Universities, Networks and the British Academic World, 1850-1939, Manchester University Press, Manchester.

Rowse, T. (1978), Australian Liberalism and National Character, Kibble Books, Melbourne.

Rutherford, E. (1915), “Henry Gwyn Jeffreys Moseley”, Nature, Vol. 96 No. 2393, pp. 33-34.

Scates, B. (2006), Return to Gallipoli: Walking the Battlefields of the Great War, Cambridge University Press, New York.

Seal, G. (2004), Inventing ANZAC: The Digger and National Mythology, UQ Press, St Lucia.

Serle, G. (1982), John Monash: A Biography, Melbourne University Press in Association with Monash University, Melbourne.

Selleck, R.J.W. (2003), The Shop: The University of Melbourne, 1850-1939, Melbourne University Press, Carlton.

Stanley, P. (2005), Quinn's Post: ANZAC, Gallipoli, Allen \& Unwin, Crows Nest.

Turney, C., Bygott, U. and Chippendale, P. (1991), Australia's First: A History of the University of Sydney. 2 Vols. University of Sydney in Association with Hale and Iremonger, Sydney.

Williams, J. (1995), The Quarantined Culture: Australian Reactions to Modernism, 1913-1939, Cambridge University Press, New York. 
Windsor, T. (2014), "Rekindling Contact: Anglo-German Academic Exchange after the First World War", in Ellis, H. and Kirchberger, U. (Eds.), Anglo-German Scholarly Networks in the Long Nineteenth Century, Brill, Leiden, pp. 212-232.

Winter, J. M. (1994), "Oxford and the First World War", in Aston, T.H. and Harrison, B. (Eds.), The History of the University of Oxford: Vol. 8, the Twentieth Century, Oxford University Press, New York, pp. 3-26.

Winter, J. M. (1995), Sites of Memory, Sites of Mourning: The Great War in European Cultural History, Cambridge University Press, New York.

Ziino, B. (2007), A Distant Grief: Australians, War Graves and the Great War, University of Western Australia Press, Crawley. 